\title{
Fermentation kinetics and protein digestibility estimation of sheep diets containing different levels of Babaçu meal and cake in vitro
}

V R Vasconcelos, A L Abdalla, M M Ramos Azevedo, A Salah Morsy, J L Rocha Sarmento, N González Ybarra, I C da Silva Bueno, M R Peçanha, L A Castinho, R C Lucas

Federal University of Piauí, Teresina, Piauí, Brazil

Email:vania@ufpi.br

Introduction The Brazilian production of Babaçu (Orbignya sp) is about 12 tons per year in an area of 10 million hectares. Babaçu meal and cake can be produced after the extraction of the oil from the nuts by solvent and mechanical pressure (respectively), which have been empirically used in the Brazilian Northeast in many ruminant production systems because of its low cost and availability in periods of feed shortage. This study was conducted to evaluate the fermentation parameters and protein digestibility of sheep diets containing different levels of Babaçu meal and cake.

Material and methods Diets (CP \% and NDF were $17.3 \%$ and 58.5\%, respectively) with four levels of Babaçu meal and cake were investigated $(0 \%$ - control, $10 \%, 20 \%$ and 30\%). Three adult rumen cannulated sheep grazing on tropical grass pasture and feed diets based on $75 \%$ corn and $25 \%$ soybean meal were used as inoculum donor for in vitro gas production according to Mauricio et al., 1999. Babaçu meal and cake samples preparation included pre-dried at $60^{\circ} \mathrm{C}$ for 48 hours and grinding. Both solid and liquid rumen fractions (1:1) were collected before the morning feeding through the cannula using a stainless steel probe attached to a large capacity syringe. Ground samples $(0.5 \mathrm{~g})$ were incubated in $25 \mathrm{ml}$ of mixed rumen fluid, $50 \mathrm{ml}$ of Menker's buffered medium in $160 \mathrm{ml}$ serum bottles (Longo et al., 2006). Once filed, all the bottles were closed with rubber stoppers shaken and placed in the incubator at $39^{\circ} \mathrm{C}$ and removed for recording of the gas headspace pressure at $6,12,24,36,48$ and $60 \mathrm{~h}$ incubation using a pressure transducer and data logger (LANA/CENAUSP, Piracicaba, SP, Brazil). Gas volume (V) was estimated by the equation: $\mathrm{V}=7.365 \mathrm{x}$ pressure (psi). After incubation the contents of bottles were used for determine the in vitro organic matter degradability (OMD). The kinetics of gas production was fitted to the exponential model proposed by France et al. (1993): A (ml) is the asymptotic gas production and $\mathrm{L}(\mathrm{h})$ is the lag time. Ruminal degradable protein (RDP) and intestinal protein digestibility (IPD) were estimated using the technique of Casalmiglia and Stern (1995). Two bags per sample with $2.0 \mathrm{~g}$ of sample were incubated in vitro for $16 \mathrm{~h}$. After that, the bags were washed and dried at $60^{\circ} \mathrm{C}$ for $48 \mathrm{~h}$. Sample residues $(0,1 \mathrm{~g})$ were incubated for $1 \mathrm{~h}$ in $10 \mathrm{ml}$ of pepsin solution at $39^{\circ} \mathrm{C}$. At the end of the incubation period, $13.5 \mathrm{ml}$ of pancreatin solution were added and incubated at $39^{\circ} \mathrm{C}$. After a $24 \mathrm{~h}$ incubation period, $3 \mathrm{ml}$ of $100 \%(\mathrm{w} / \mathrm{v})$ trichloroacetic acid (TCA) solution was add to precipitate the undigested proteins and supernatant used for measure the $\mathrm{N}$ content. Data were subjected to analysis of variance (ANOVA) using the General Linear Model procedure (SAS, 1999).

Results There was no significant effect $(P>0.05)$ of the different levels of Babaçu meal and cake on A $(327 \mathrm{~mL} / \mathrm{g} \mathrm{DM}) \mathrm{and}$ L (1.6h) parameters of gas production. Similarly, there was no effect $(\mathrm{P}>0.05)$ for the average of the 3 experimental levels in OMD (65.4\%), RPD (51.6\%) and IPD (75.2\%). Gas production kinectics during $60 \mathrm{~h}$ of incubation period is shown in Figure 1. No differences observed ( $P=0.10$ and $P=0.09$, respectively) for dry matter (DM) cumulative gas production and

$3 \mathrm{sc}$

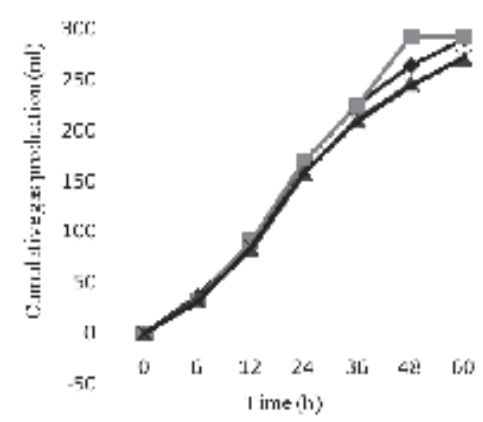
organic matter (OM) cumulative gas production.

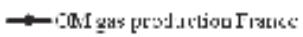
IJ.sidid IJ.cods

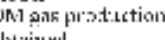
alstiaine

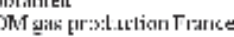
irs:clel

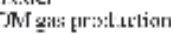
abtaisud

Conclusion This study suggested that the Babaçu meal and cake have no harmful effect on fermentation kinetics and protein digestibility in vitro. Once such properties have also been demonstrated in vivo, Babaçu meal and cake may be used as an alternative feed source in ruminant nutrition in Brazilian Northeast.

Acknowledgement This work was supported by CAPES, a Brazilian Government Agency.

Figure 1 Cumulative gas production kinectics during $60 \mathrm{~h}$ of incubation period

\section{References}

Calsamiglia, S, Stern MD. 1995 Journal of Animal Science, 73, 1459-1465.

France, J, Dhanoa, MS, Theodorou, MK, Listers, SJ, Davies, DR, Isac, D1993 Journal of Theoretical Biology, 163, 99-111. Longo, C, Bueno, ICS, Nozella, EF, Godoy, PB, Cabral Filho, SLS, Abdalla, AL. 2006. In: International Congress Series, 1293,6265

Mauricio, RM, Mould, FL, Dhanoa MS, Owen E, Channa, KS.Theodorou, MK. 1999. Animal Feed Science and Technology, 79, 312-330

Statistical Analysis Systems. (1999). User's guide: statistics. Version 8.0. Cary. (CD-ROM). 